\title{
Failure Analysis of Pressure Letdown Valve From the Synthoil Process Development Unit
}
D. P. Edmonds
D. A. Canonico
B. C. Leslie

\section{OAK RIDGE NATIONAL LABORATORY}

OPERATED BY UNION CARBIDE CORPORATION FOR THE ENERRYY RFSFARTH ANII UIEVELOPMENT ADMINISTRATION 


\section{DISCLAIMER}

This report was prepared as an account of work sponsored by an agency of the United States Government. Neither the United States Government nor any agency Thereof, nor any of their employees, makes any warranty, express or implied, or assumes any legal liability or responsibility for the accuracy, completeness, or usefulness of any information, apparatus, product, or process disclosed, or represents that its use would not infringe privately owned rights. Reference herein to any specific commercial product, process, or service by trade name, trademark, manufacturer, or otherwise does not necessarily constitute or imply its endorsement, recommendation, or favoring by the United States Government or any agency thereof. The views and opinions of authors expressed herein do not necessarily state or reflect those of the United States Government or any agency thereof. 


\section{DISCLAIMER}

Portions of this document may be illegible in electronic image products. Images are produced from the best available original document. 


\section{Printed in the United States of America. Available from National Technical Information Service \\ U.S. Department of Commerce 5285 Port Royal Road, Springfield, Virginia 22161 \\ Price: Printed Copy $\$ 4.00$; Microfiche $\$ 3.00$}

This report was prepared as an account of work sponsored by the United States Government. Neither the United States nor the Energy Research and Development Administration/United States Nuclear Regulatory Commission, nor any of their employees, nor any of their contractors, subcontractors, or their employees, makes any warranty, express or implied, or assumes any legal liability or responsibility for the accuracy, completeness or usefulness of any information, apparatus, product or process disclosed, or represents that its use would not infringe privately owned rights. 
ORNL/TM-5742

Distribution

Category UC-90d

Contract No. W-7405-eng-26

METALS AND CERAMICS DIVISION

FAILURE ANALYSIS OF PRESSURE LETDOWN VALVE FROM THE SYNTHOIL PROCESS DEVELOPMENT UNIT

D. P. Edmonds, D. A. Canonico, and B. C. Leslie

Date Published: January 1977

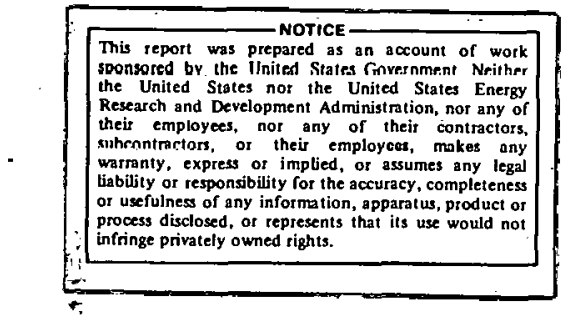

OAK RIDGE NATIONAL LABORATORY

Oak Ridge, Tennessee 37830

operated by

UNION CARBIDE CORPORATION

for the

ENERGY RESEARCH AND DEVELOPMENT ADMINISTRATION 
THIS PAGE

WAS INTENTIONALLY

LEFT BLANK 
CONTENTS

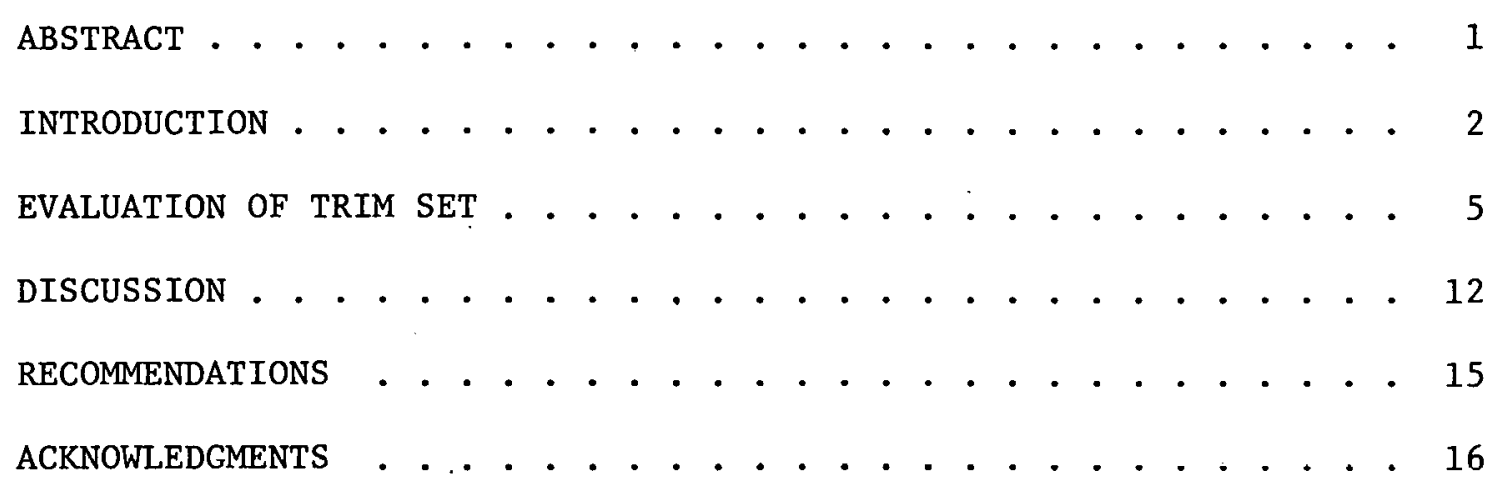


FAILURE ANALYSIS OF PRESSURE LETDOWN VALVE FROM THE SYNTHOIL PROCESS DEVELOPMENT UNIT

D. P. Edmonds, D. A. Canonico, and B. C. Leslie

\begin{abstract}
Several processes are being developed to convert coal with high sulfur and ash contents to fuel oil with significantly lower concentrations of these constituents. One such process is Synthoil, a one-step hydrodesulfurization process, which accomplishes over $94 \%$ conversion to oil (No. 2 to No. 6 fuel oils) in a short time. The reaction is carried out at temperatures around $450^{\circ} \mathrm{C}\left(842^{\circ} \mathrm{F}\right)$ and pressures of 13.7 and $27.5 \mathrm{MPa}$ gage (2000 and 4000 psig). Many surfaces in this system are subject to excessive wear because of the severe operating conditions and the abrasiveness of the coal. One such problem area is the pressure letdown valve on the product oil line. At the $900 \mathrm{~kg} /$ day ( $1 / 2$ ton/day) Process Development Unit at the Pittsburgh Energy Research Center, these valves, which operate at a pressure differential of $27.5 \mathrm{MPa}$ (4000 psi) and a temperature of $125^{\circ} \mathrm{C}\left(257^{\circ} \mathrm{F}\right)$ must be replaced after about $1000 \mathrm{hr}$.

We have examined one of these valves that had failed in a typical manner after $915 \mathrm{hr}$. It contained a replaceable trim set made of cemented tungsten carbide inserts that had been brazed to the valve plug and press-fitted to the valve seat. Failure of the valve was due to localized erosion of the tungsten carbide inserts. The failure mode was preferential erosion-corrosion of the cobalt-chromium binder, allowing the hard tungsten carbide particles to be washed away in the product oil. We built a full-scale Plexiglas model of the valve and found that slight misalignments of the plug with respect to the seat cause large changes in flow patterns through the valve.

Many factors can change the local rate of erosion at a plug-to-seat region, such as differences in the abrasive and corrosive characteristics of the slurry, its local velocity, and angle of attack. Other factors are local variations in the composition, structure, corrosion resistance, and wear resistance of the seat and plug. In this case eccentricity of the trim set probably contributed to uneven flow around the plug, and progressively higher local flow rates with increasing wear caused fallure. The eccentricity may have arisen during manufacture [and indeed, holding tolerance of $0.038 \mathrm{~mm}$ ( 0.0015 in.) in commercial valves seems difficult] or during service as a result of cracking of the stem-totip braze.
\end{abstract}




\section{INTRODUCTION}

Several processes are currently being developed to convert coal with high sulfur and ash contents to fuel oil with significantly lower concentrations of these constituents. One such process is Synthoil, a one-step hydrodesulfurization process, which accomplishes over $94 \%$ conversion to oil (No. 2 to No. 6 fuel oils) in a short reaction time. A flowsheet for the Synthoil pilot plant (being developed at the Pittsburgh Energy Research Center - PERC) is shown in Fig. 1. A slurry of coal in recycled "carrier" oil is pumped through a fixed bed of cobalt-molybdenum catalyst pellets at temperatures around $450^{\circ} \mathrm{C}\left(842^{\circ} \mathrm{F}\right.$ ) and pressures of 13.7 and $27.5 \mathrm{MPa}$ gage (2000 and 4000 psig). The slurry flow is enhanced by turbulent flow of pressurized hydrogen through the catalyst bed. Sulfur is removed in the form of hydrogen sulfide, and ash is centrifuged from the product oil.

Many surfaces in this system are subject to severe wear because of the operating conditions and the abrasiveness of the coal particles. One such problem area is the pressure letdown valve on the product oil line, between the high- and low-pressure receivers (see Fig. 1). The primary purpose of this valve is to maintain the correct pressure in the operating unit, while passing the product oil. At the $900 \mathrm{~kg} / \mathrm{day}$ ( $1 / 2$ ton/day) Process Development Unit at PERC, these valves must be replaced after an average of $1000 \mathrm{hr}$ operating at a pressure differential of $27.5 \mathrm{MPa}(4000 \mathrm{psi})$ and a. temperature of $125^{\circ} \mathrm{C}\left(257^{\circ} \mathrm{F}\right)$.

We have examined one of these valves that failed in a typical manner after $915 \mathrm{hr}$. The total mass of liquids (which contained 5-6\% residual solids of a size distribution unknown to the authors) let down through the valve was $10,377 \mathrm{~kg}(22,875 \mathrm{lb})$. The valve trim set, shown in Fig. 2, was inspected visualiy and dimensionally and examined by metallographic techniques, which included optical and scanning electron microscopy, microprobe analysis, and microhardness measurements. A ful1-scale Plexiglas model was built, and the flow pattern of liquid through the letdown valve was studied. 
ORNL DWG 75-643

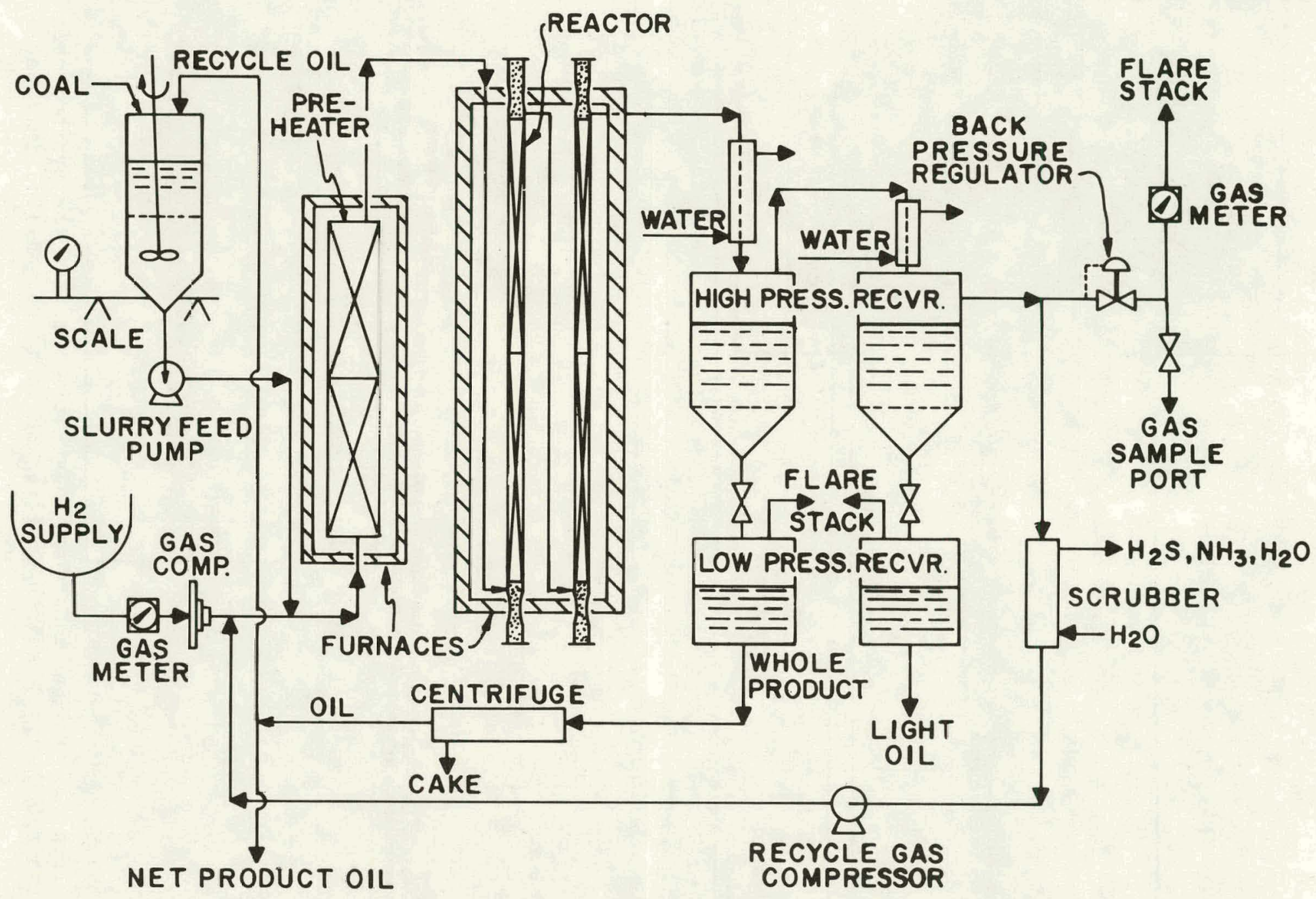

Fig. 1. Synthoil Pilot Plant Flowsheet. 


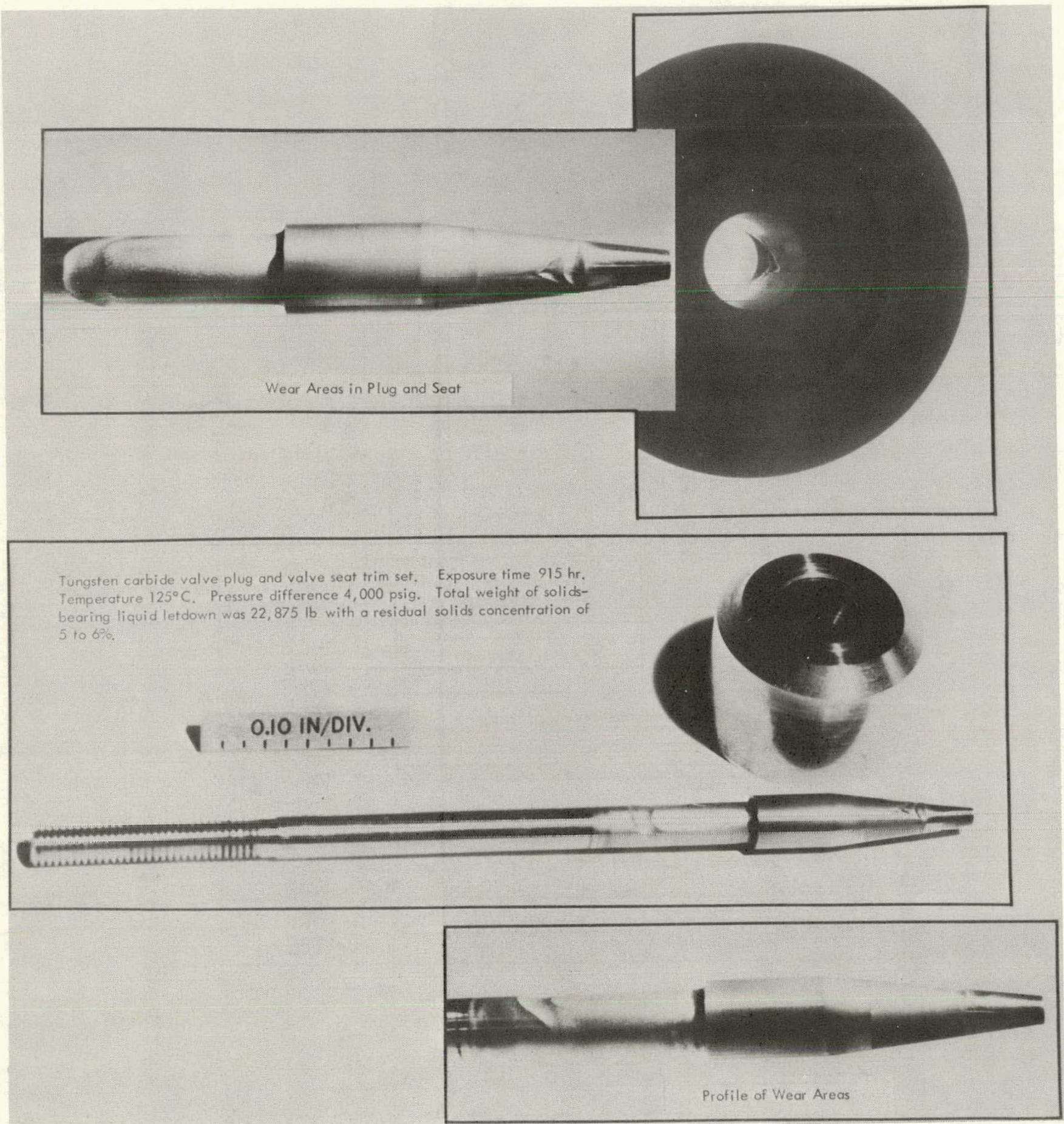

Fig. 2. Pressure Letdown Valve Trim Set from the Synthoil Plant at Pittsburgh Energy Research Center. Scale is $2.5 \mathrm{~mm}$ (0.1 in.) per division. 


\section{EVALUATION OF TRIM SET}

The valve plug and seat eroded on the seat insert and the plug tip and stem (Fig. 2). A dimensional inspection of the trim set showed a concentricity deviation of $33 \mu \mathrm{m}$ (0.0013 in.) between the plug tip and stem. Ovality of the plug tip was noted at its nib, but it did not extend into the mating area.

The valve plug and seat were sectioned and metallographically examined. A longitudinal section through the valve seat is shown in Fig. 3. The Kennametal grade $\mathrm{K} 701$ insert was apparently press-fit into the valve seat, since we found braze material absent from the seat insert joint and indications of plastic deformation of the stainless steel valve seat. The longitudinal section through the seat insert in Fig. 4 shows the eroded area in the lower right corner. This eroded area is shown at higher magnification in Fig. 5. No indications of preferential erosion-corrosion of any phase present in the microstructure could be determined from the optical metallography.

A longitudinal section of the valve plug at the braze joint is shown in Fig. 6. A semiquantitative electron microprobe analysis on this plug tip-to-stem joint found the braze metal to be silver rich, with about $6 \% \mathrm{Cu}$ and $13 \% \mathrm{Zn}$. The braze metals that are most commonly used for tungsten carbide tip brazing are the AWS BAg-3 and BAg-4 (silver base) materials. Possibly one of these alloys was used here. The entire length of the braze is cracked in the plane along the center axis of the tip. In most cases this crack did not propagate through the fillet. However, in some areas, such as the one shown in Fig. 7(a), the crack propagated through to the surface. Also, much porosity [Fig. 7(b)] was observed on the surface of the braze. This extensive cracking could have caused the observed eccentricity of the tip with respect to the stem. Problems with braze joints in tungsten carbide valve tips were also encountered in Project Lignite. ${ }^{1}$

\footnotetext{
${ }^{1}$ D. E. Severson, Project Lignite Quarterly Technical Progress Report No. 6, July, August, and September 1975, FE-1224-49 (Dec. 22, 1975), p. 9.
} 
$Y-137738$

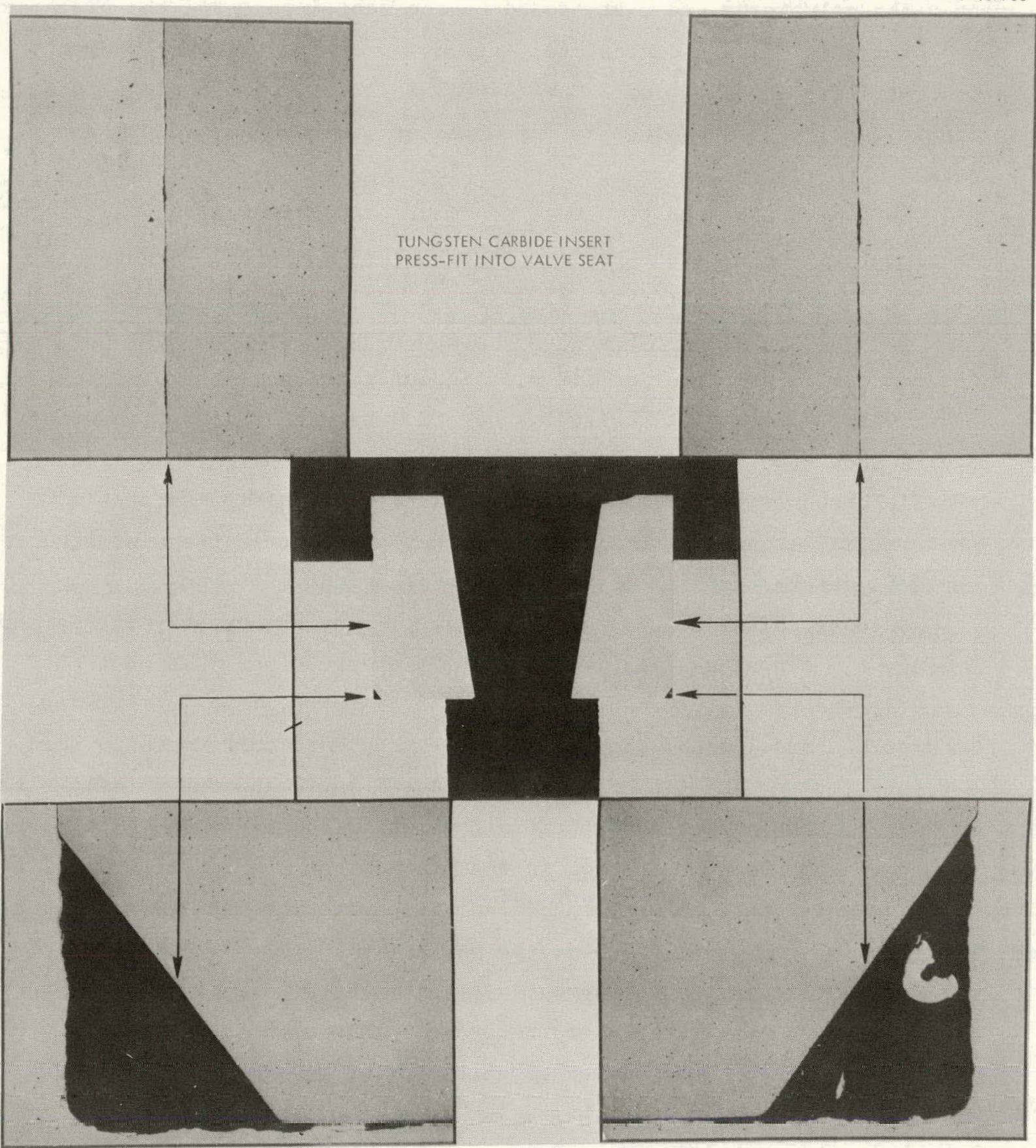

Fig. 3. Longitudinal Section of Pressure Letdown Valve Seat with Insert. 


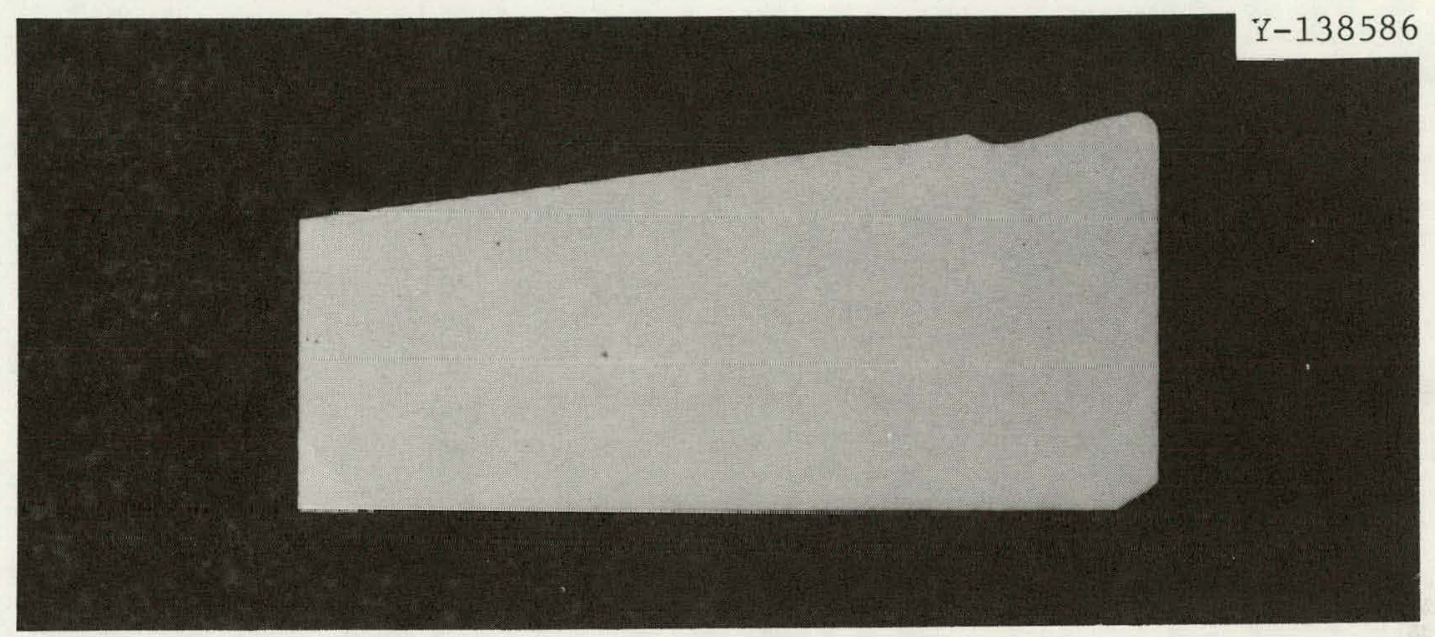

Fig. 4. Longitudinal Section of Valve Seat Insert. 12x.

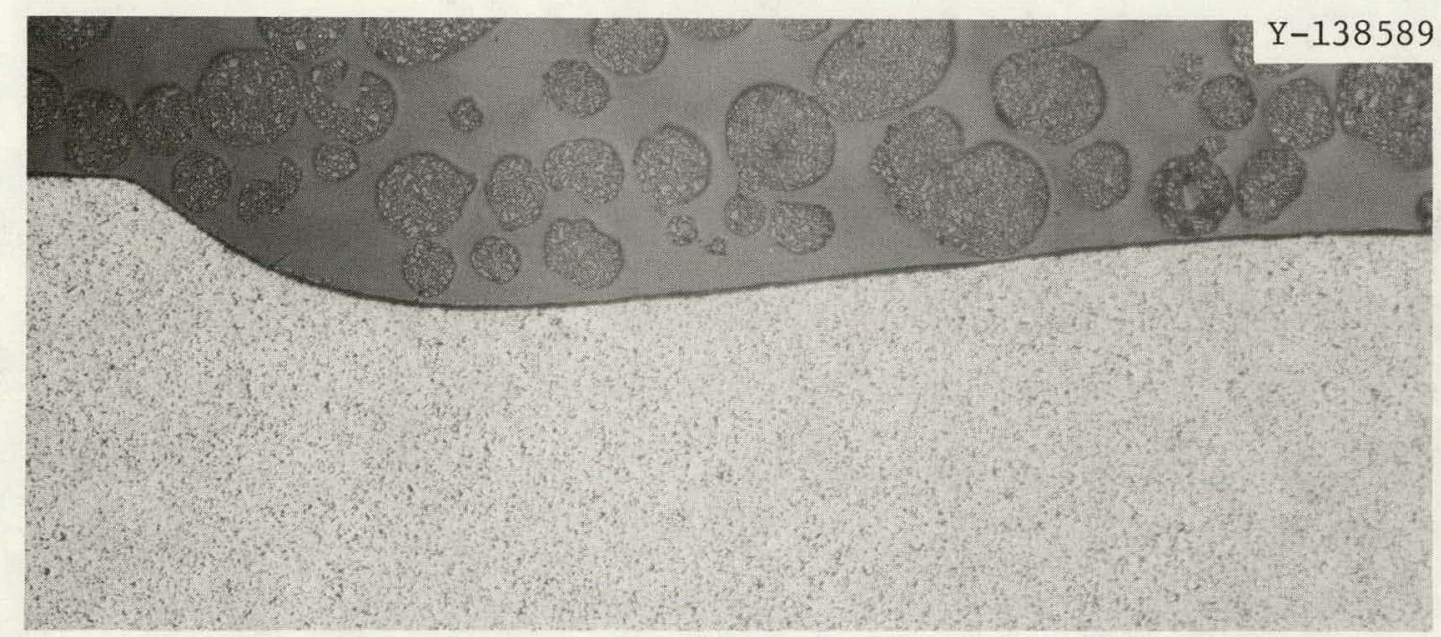

Fig. 5. Longitudinal Section of Eroded Area on Valve Seat Insert. $100 \times$. 


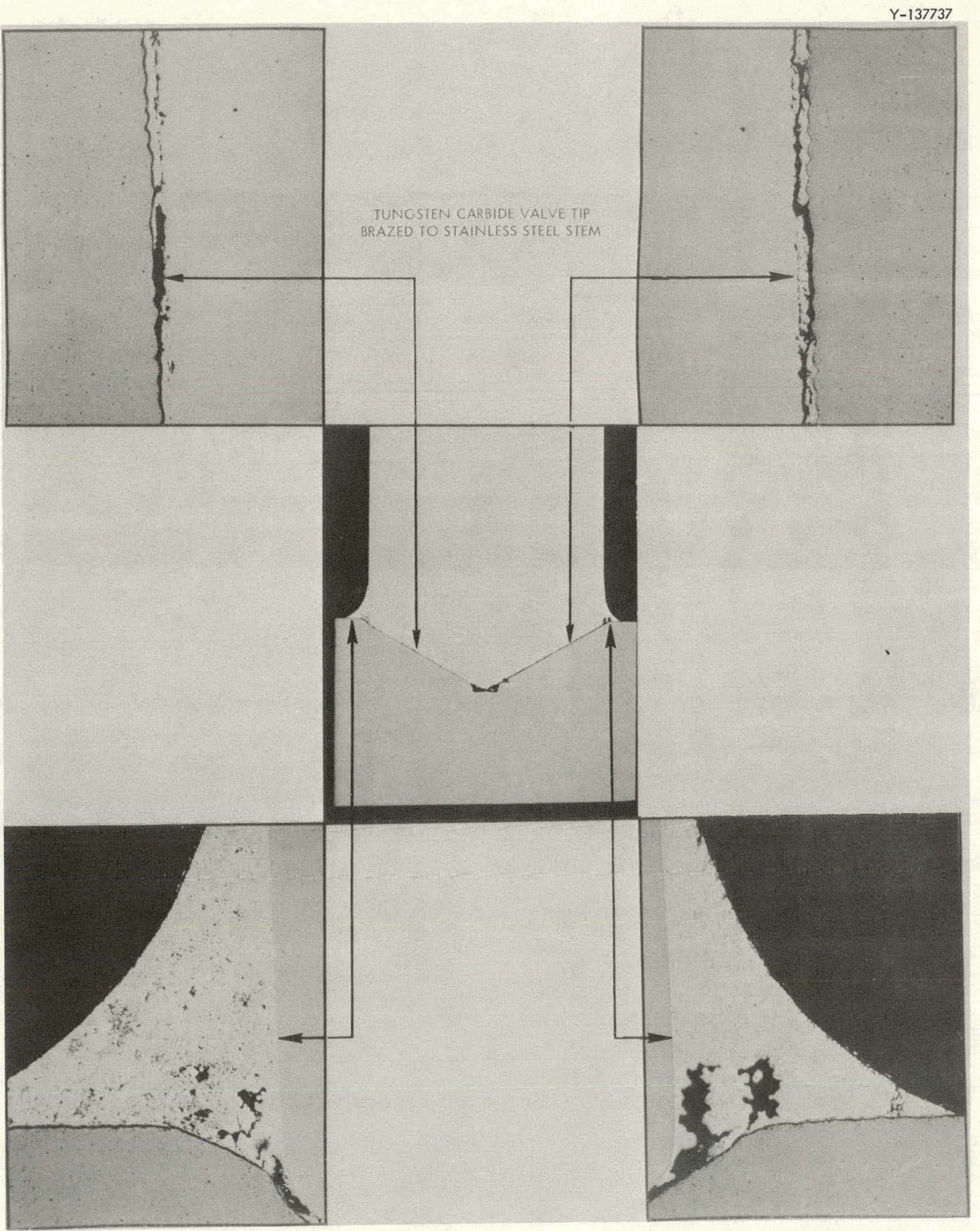

Fig. 6. Longitudinal Section of Pressure Letdown Valve Plug Braze Joint. 

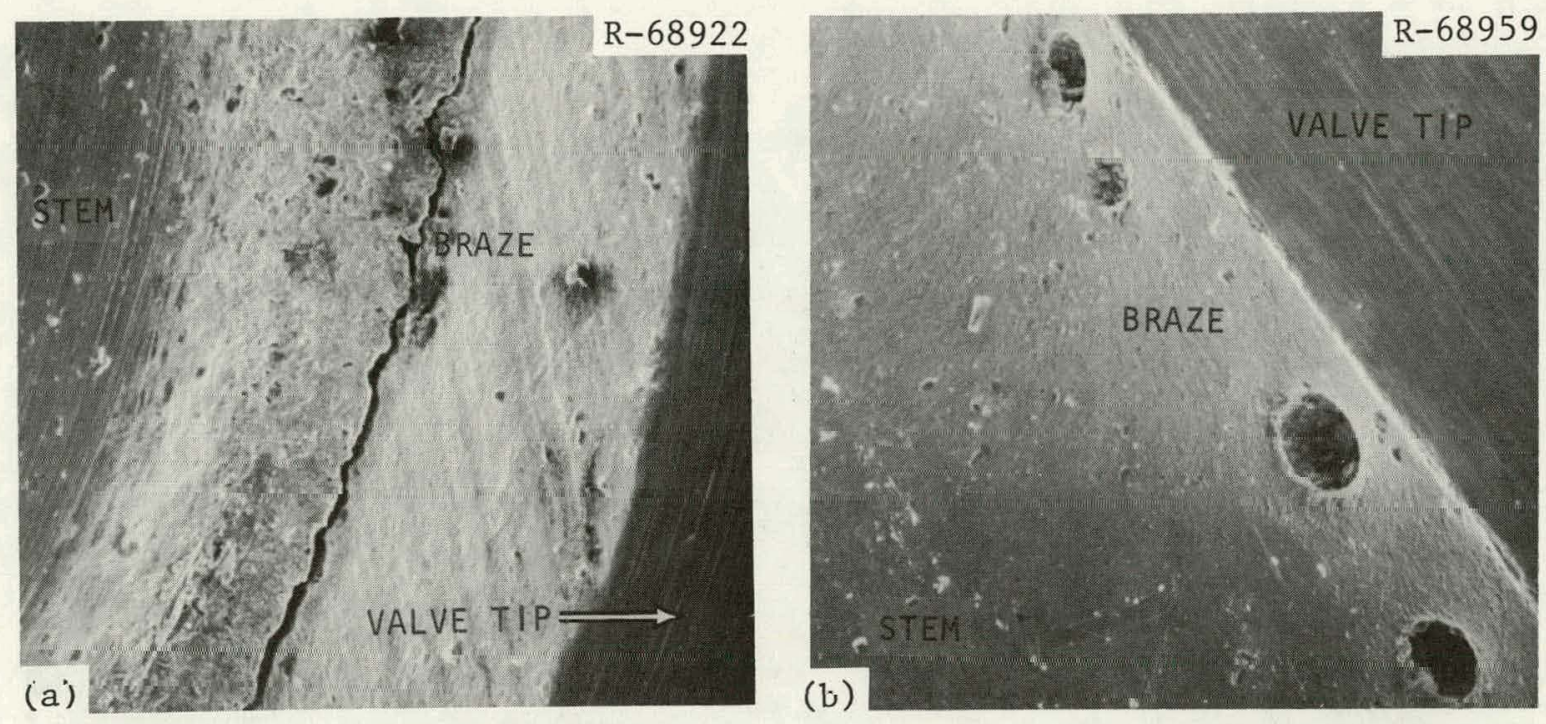

Fig. 7. Scanning Electron Micrographs of Valve Tip Braze. 50x (a) Crack in braze. (b) Porosity in braze.

The longitudinal section of the Kennametal grade K701 valve plug tip in Figs. 8 and 9 shows the areas of localized erosion on the plug. Similar to the evaluation of the seat, optical metallography detected no preferential erosion-corrosion of phases present. The Kennametal grade K701 material (Fig. 10) is a cemented tungsten carbide with 8 to $10 \%$ cobalt-chromium binder. The gray areas in Fig. 10 are tungsten carbide with an average grain size of $2 \mu \mathrm{m}$, and the white areas are the binder. The black phase is a carbon-deficient carbide phase known as eta $\left(\mathrm{Co}_{3} \mathrm{~W}_{3} \mathrm{C}\right)$. Areas close to the surface, especially at the corners and tip (Figs. 4 and 8 ), had relatively little eta phase. The average hardness of areas was 1528 DPH where eta phase was present and $1429 \mathrm{DPH}$ where eta phase was deficient. Erosion occurred both in areas where eta was present (seat insert) and where eta was deficient (plug tip). Therefore, within the limits of this investigation the presence of eta phase in the microstructure is apparently not a major determinant of whether localized erosion will occur.

Scanning electron microscopy of the valve plug tip and seat insert revealed no noticeable differences between the surfaces of areas where general erosion and localized erosion had occurred. Also, the eroded areas on the plug tip were similar to those on the seat insert. A scanning electron micrograph of a typical eroded area is shown in Fig. 11. 


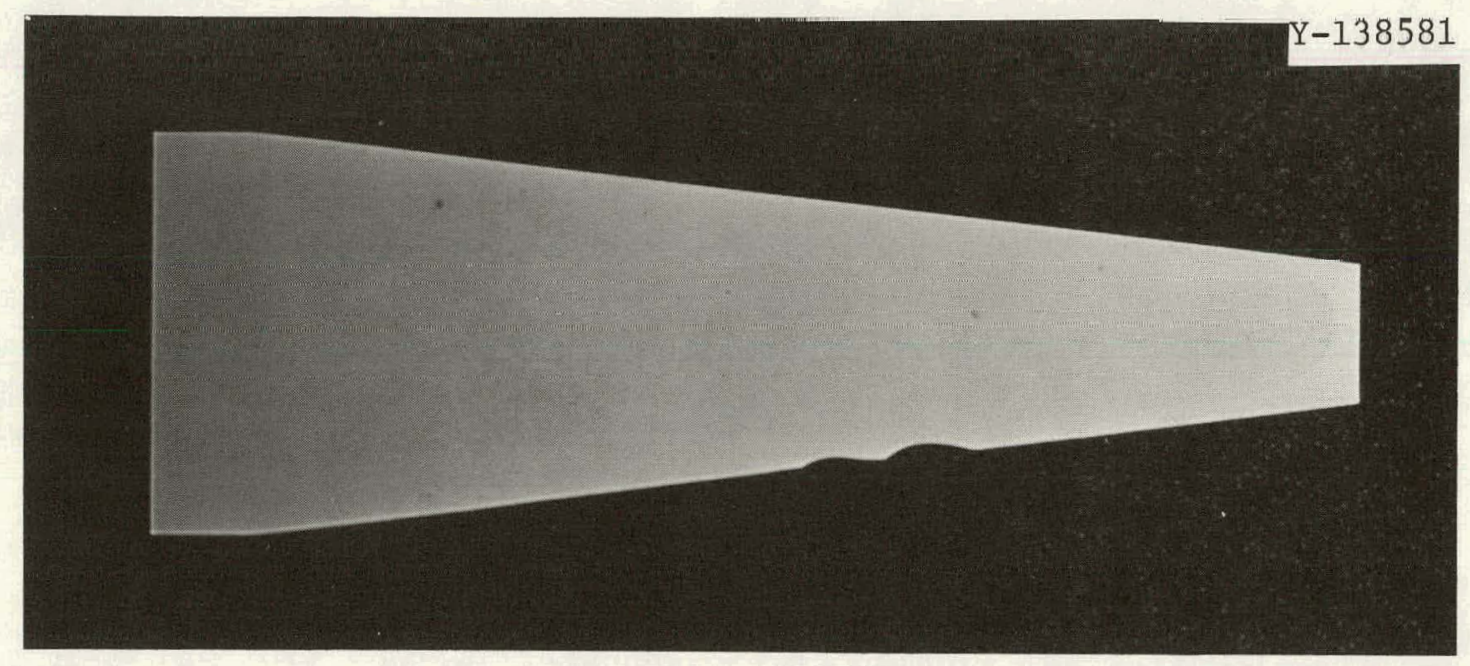

Fig. 8. Longitudinal Section of Valve Plug Tip. 6×.

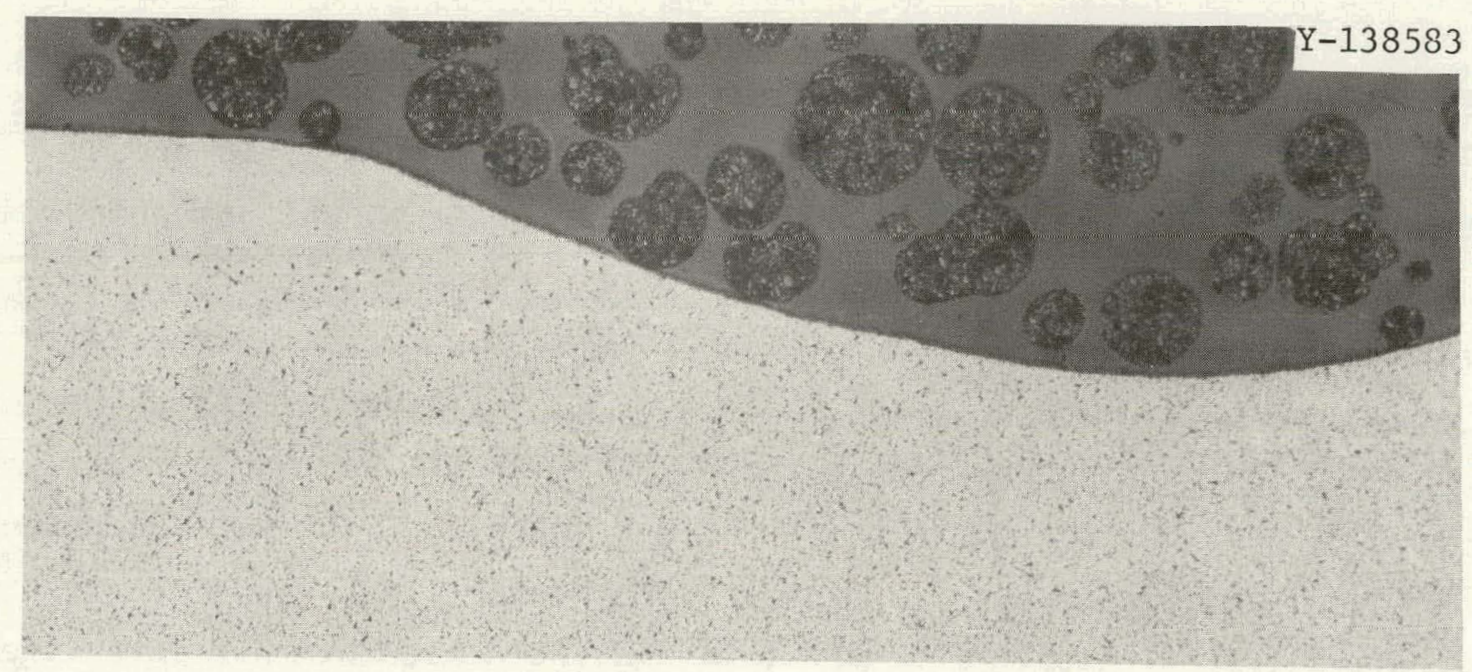

Fig. 9. Longitudinal Section of Eroded Area on Valve Plug Tip. $100 \times$. 


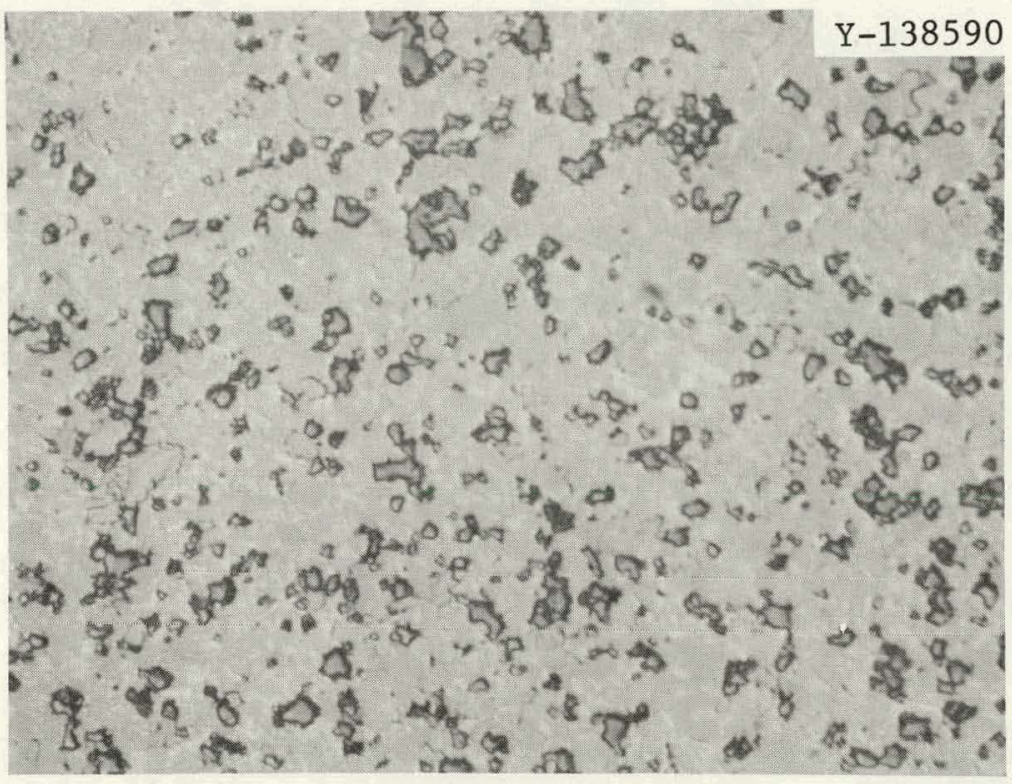

Fig. 10. Kennametal Grade K701 Microstructure. 1500×.

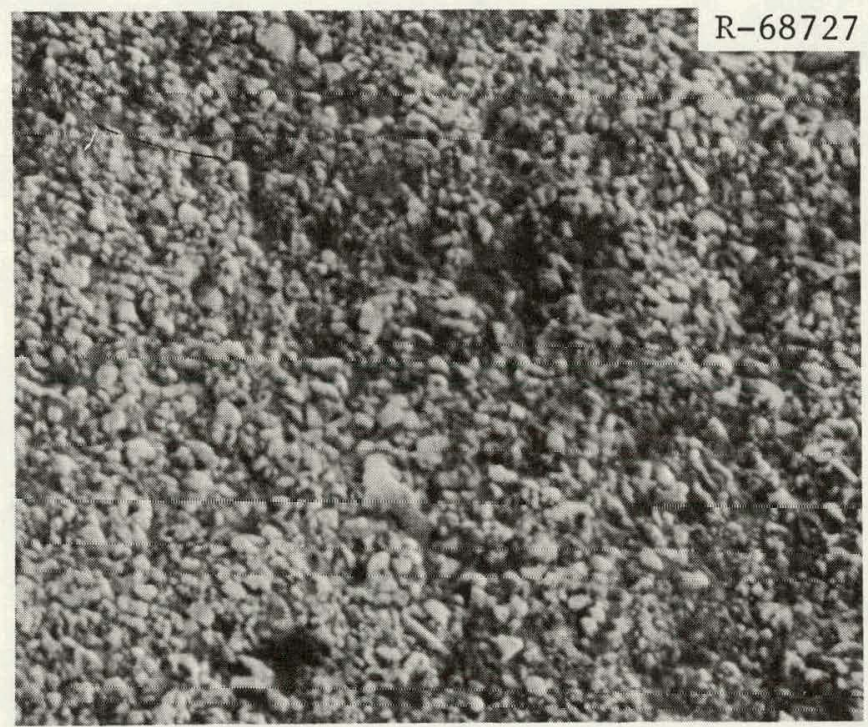

Fig. 11. Scanning Electron Micrograph of Typical Eroded Area of the Kennametal Grade K701. 1000x. 
The tungsten carbide grains are projecting from the eroded surface in this figure. This indicates that the cobalt-chromium binder has been eroded-corroded from between the carbide particles. Presumably, all the binder eventually erodes from between the carbide particles, allowing them to be washed away in the product oil. This condition could not be resolved with conventional optical metallography.

We concluded that localized erosion of the Kennametal inserts caused the failure of the trim set. This erosion was related to local flow patterns. We suspect that the region of high erosion is related to the misalignment between the plug and serl. To evaluate this hypothesis we built a full-scale Plexiglas model of the valve (Fig, 12) and examined the flow patterns of liquids past the trim set, with fine carbon particles suspended in water and with a milling yellow die suspension, which is sensitive to polarized light. A suspension of fine carbon in water and a special lighting technique were used to examine flow with the tip misaligned and in contact with the seat at the side opposite the outlet (Fig. 13). Under these conditions most of the flow enters the mixing chamber through the inlet on the side adjacent to the outlet. Part of the liquid flows directly out through the outlet but part swirls through the chamber and then through the outlet. We believe that a similar situation occurred in the failed valve, with most of the flow confined to one side of the seat and tip. This may account for the localized erosion of the tip and seat insert. The erosion of the stem was probably due to swirling of the liquid in the mixing chamber.

\section{DISCUSSION}

The tesulls of our postservice examination of the trim set are summarized below:

1. Tailure of the valve was a result of localized erosion of the trim set.

2. A concentricity deviation of $33 \mu \mathrm{m}(0.0013 \mathrm{in.})$ existed between the valve plug tip and stem. 


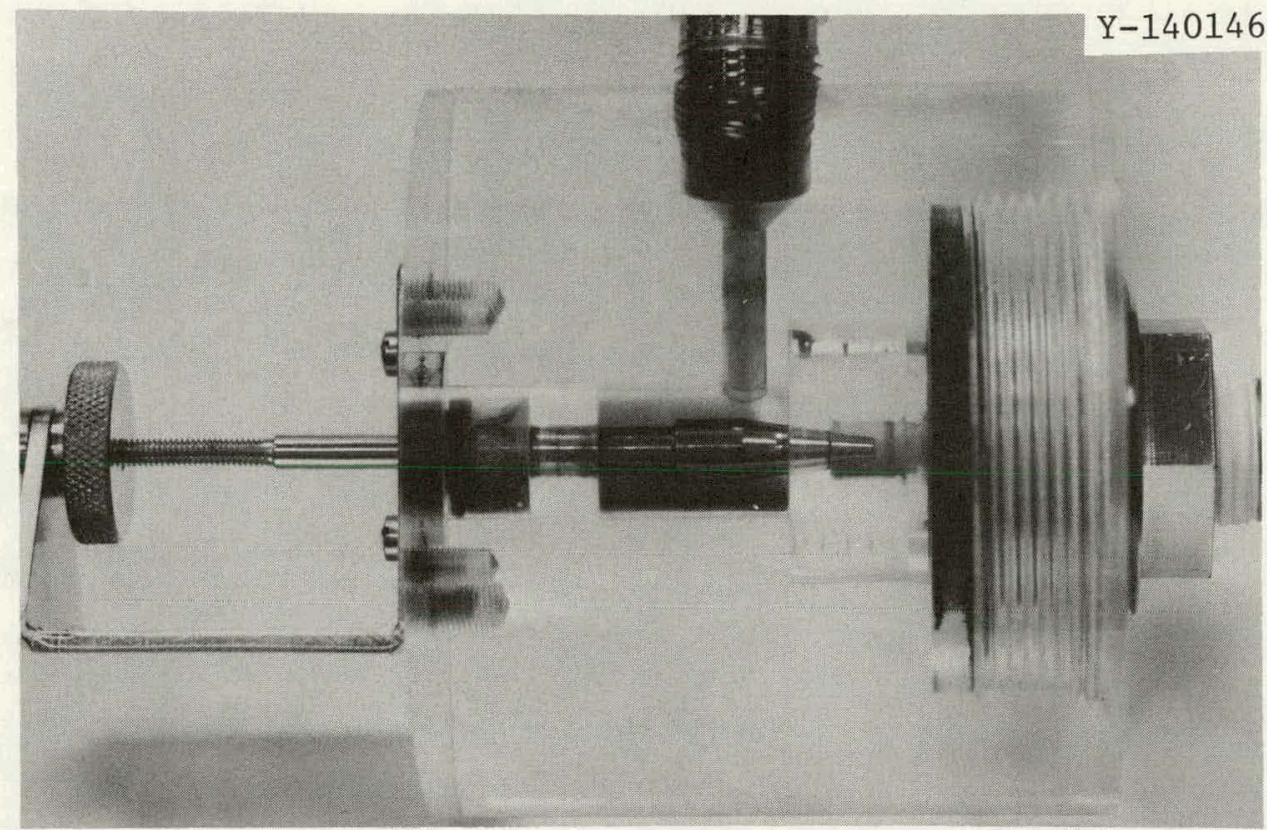

Fig. 12. Ful1-Scale Plexiglas Model of Pressure Letdown Valve $(\sim 1.3 \times)$.

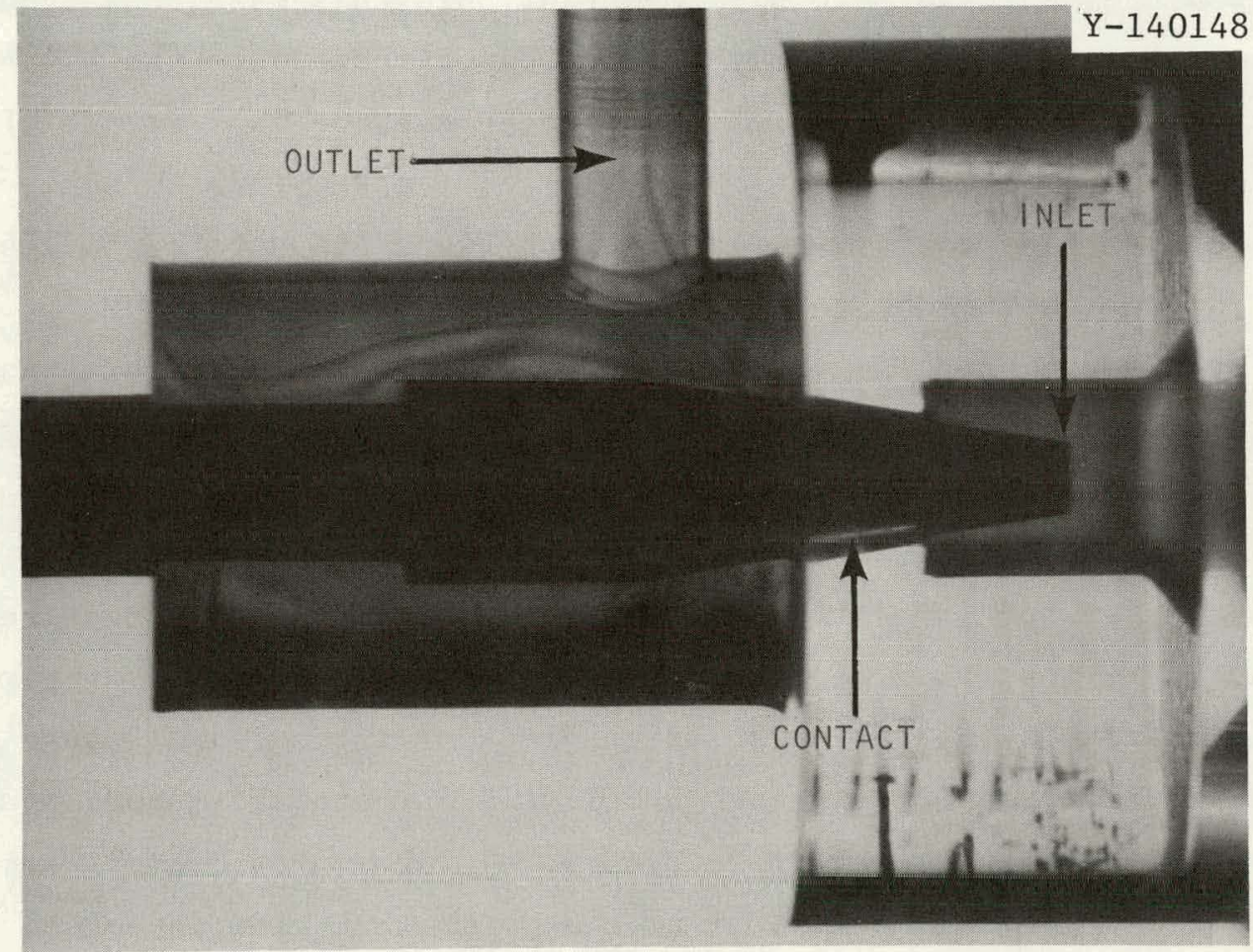

Fig. 13. Flow Pattern Through Valve with Tip Making Contact with Seat on One Side. 
3. The braze between the tip and stem was severely cracked.

4. Slight misalignments of the trim set can localize the flow of liquids to one side of the plug and seat.

5. The mechanism of erosion was preferential erosion-corrosion of the cobalt-chromium binder in the cemented tungsten carbide inserts.

A detailed model for erosion of multiphase materials by corrosive liquids that carry abrasive solids is not yet available. Qualitatively, however, a number of variables can be identified as being likely to play a role, including characteristics of liquid, particulate, and eroding solid. The velocity of the liquid, its angle of impingement on the solid, viscosity, and temperature are all key variables. The size distribution of the particulate matter, its morphology, and its hardness (or deformation characteristics) are critical, when particulates are mainly responsible for erosion. For multiphase materials, the size distribution of the hard phase and interstice area exposed to attack, and the deformation and corrosion-resistant characteristics of the softer binder material are all important. In this case, the apparent mode of attack is erosion (maybe aided by corrosion) of the binder by a slurry flowing nearly parallel to the wear surface as a result of the "nearly closed" operation of the valve $[\sim 3.1 \mathrm{~g} / \mathrm{sec}(\sim 25 \mathrm{lb} / \mathrm{hr})$ weepage]. Particulates fine enough to easily fit between the hard particlcs of the wear surface impinge on the binder and gradually remove it.

We suspect that the preferential erosion pattern in this case can be traced to differences in local flow velority past the mating ourfacco of the valves. At least two fartors can contribute to initial

nonuniform flow: (1) normal flow patterns due to the nonsymmctrical design of the valve, and (2) differences in the local opening that arise from eccentricity (or other geometric irregularities) of the valve tip and seat at their mating surfaces. Regardless of the original cause of eccentric flow, regions of high local velocity probably erode preferentially, leading to ever-increasing local flow rates, until the mating surfaces are gouged out locally to the point that flow cannot be controlled to the desired level. 
It is difficult to deduce the original cause of eccentric flow from this post-test analysis. Normal flow patterns can differ with total flow rate in any valve configuration. We cannot determine whether the failed valve would have had eccentric flow at its operating flow rate if the tip and seat had been perfect geometrically and concentric. The observed $33 \mu \mathrm{m}$ ( $0.0013 \mathrm{in.})$ deviation from concentricity is not làrge and probably represents good manufacturing practice for commercial valves. There is no way to determine whether the braze material was cracked during the manufacturing process or whether it cracked in service, perhaps during an attempt to close the valve late in 1ts service life.

In order to understand the nature of valve erosion processes under the service conditions encountered in the Synthoil process, valves should be subjected to both preservice and postservice inspections. Further information could. be gained from periodic, removal of valves from service and inspection of the wearing surfaces. Also, dissection of test valves from the same batches to be used in the process would allow the initial soundness of brazed joints to be adequately characterized.

\section{RECOMMENDATIONS}

In order to improve valve life for the Synthoil letdown application, several factors must be considered:

1. Valve design. Designs that lead to concentric flow patterns can be identified only on the basis of fluld fluw experimenta. It seems unlikely that a single inlet or single exit close to the mating surfaces would be desirable. Other considerations, such as the proper length of mating surfaces, angle relative to the axis, and geometry are beyond the scope of this investigation but could properly be the subject of a study.

2. Manufacturing precision and quality. Any geometrical irregularity at the mating surfaces, including lack of concentricity, can contribute to nonuniform flow. Commercial products should be characterized to 
determine normal tolerances and whether more precise tolerance control should be considered. Concurrent consideration of designs that improve alignment is also recommended.

3. Wear materials. Screening erosion tests of a range of erosion-resistant materials should be performed under prototypic conditions that eliminate other confounding variables. We feel that minimizing the amount of binder material is desirable to reduce wear in this case. Longer range research to understand and minimize wear processes is also Indicated.

4. Improved brazing materials. Whether the braze cracked in service or during fabrication, the cause of the braze tip failure should be identified and a better material found for the application.

5. Other faizure modes. Elimination of the present mode of failure will undoubtedly shift the eventual valve failurc to some other mode, such as wear of the stem. Identification and prevention of other failure modes should be a part of the overall program. Evaluation of a sufficient number of failed valves, or valves that have seen some service, is desirable.

\section{ACKNOWLEDGMENTS}

The authors gratefully acknowledge technical discussions with J. P. Hammond, R. T. King, W. R, Martin, A. .T. Mnnrhesd, and G. M. Slaughter. The help of J. M. Cesarini with the valve model, R. S. Crouse in performing electron microprobe and scanning electron microscopy analyses, R. H. Cooper and R. T. King for reviewing the paper, Sigfred Peterson for editing, and Denise Jackson for the final preparation of the report are also recognized. 
ORNL/TM-5742

Distribution

Category UC-90d

\section{INTERNAL DISTRIBUTION}

1-2. Central Research Library

3. Document Reference Section

4-8. Laboratory Records Department

9. Laboratory Records, ORNL RC

10. ORNL Patent office

11. G. M. Adamson

12. S. I. Auerbach

13. R. J. Beaver

14. N. E. Bolton

15. C. R. Brinkman

16. D. A. Canonico

17. G. W. Clark

18. H. D. Cochran, Jr.

19. R. A. Cooper

20. R. H. Cooper, Jr .

21. J. E. Cunningham

22. J. H. DeVan

23. J. R. DiStefano

24. R. G. Donnelly

25. W. P. Eatherly

26-34. D. P. Edmonds

35. M. S. Edwards

36. D. E. Ferguson

37. L. M. Ferris

38. R. C. Forrester III

39. A. P. Fraas

40. W. Fulkerson

41. G. M. Goodwin

42. J. C. Griess, Jr .

43. R. L. Heestand
44-46. M. R. Hill

47. J. M. Holmes

48. $\mathrm{H}$. Inouye

49. J. R. Keiser

50. R. T. King

51. W. R. Laing

52. C. T. Liu

53. H. E. McCoy

54. R. W. McClung

55. D. L. McElroy

56. C. J. McHargue

57. J. R. McWherter

58. R. K. Nanstad

59. J. P. Nichols

60. T. W. Pickel

61. W. W. Pitt

62. H. Postma

63. T. K. Roche

64. M. W. Rosentha1

65. A. C. Schaffhauser

66. C. D. Scott

67. J. E. Selle

68. W. D. Shults

69. G. M. Slaughter

70. J. 0. Stiegler

71. V. S. Tennery

72. D. B. Trauger

73. J. R. Weir, Jr.

74. J. C. Wh1te

EXTERNAL DISTRIBUTION

75-90. ERDA, Washington, DC 20545
W. Baker, FER
J. D. Batchelor, CCU
E. L. Clark, CCU
N. P. Cochran, FDP
T. Cox, FER
S. J. Dapkunas, FER
J. Forst, FE
H. Franke1, FF:

D. Garret, FDP

S. W. Fouse, FE

W. S. Harmon, FDP

L. Kindley, FER

C. Knudsen, FER

T. K. Lau, FDP

J. Smith, FE

D. K. Stevens, DPR 
EXTERNAL DISTRIBUTION (Continued)

91-95. Morgantown Energy Research Center, P.0. Box 800, Morgantown, WV 26506

Director

96-97. ERDA Pittsburg Energy Research Center, 4800 Forbes Avenue, PA 15213

W. P. Haynes

J. P, Strakey

98. ERDA Fossile Energy Analyst, Office of Congressinna1. Relations, Warhington, DC 20545

David 0. Webb

99. ERDA OAK RIDGE OPERATIONS OFFICE, P.O. BOX E, Oak Ridge, TN 37830

Research and Technical Support Division

100-352. ERDA TECHNICAL INFORMATION CENTER, Office of Information Services, P.0. Box 62, Qak Ridge, TN 37830

For distribution as shown in TID-4500 Distribution Category, UC-90d (Coal Conversion and Utilization - Liquefaction) 